\title{
The Effect Of Road Narrowing On The Traffic Characteristics
}

\author{
Reza Yoga Widya Baskara*, Atik Wahyuni, Farida Hardanignrum \\ Department of Civil Engineering, Faculty of Engineering, Narotama University, Indonesia \\ *Corresponding author e-mail: rezayoga43@gmail.com
}

\begin{abstract}
Manuscript received 23 Feb 2021; revised 2 March. 2021; accepted 15 March 2021. Date of publication 2 April 2021

A problem found in transportation is road narrowing. Road narrowing refers to a condition in which its downstream is smaller than the upstream. This research took place on Ahmad Yani Street at the front of Royal Plaza, Surabaya. The location of this research had a sufficiently high traffic flow. Thus, the road should be able to operate optimally. In fact, there is still a density caused by road narrowing. This research was intended to determine how much the maximum flow, maximum density and free speed on the road before, during and after the narrowing. Besides, this research was carried out to find out the relation of the flow, the traffic density and speed, determine the value of the shock waves during the road narrowing. This research was done on Wednesday and Saturday morning, at 06:00-08:00 and in the afternoon at 16:00-18:00. The calculation performed was based on Greenshield method. The analysis revealed that the largest maximum flow was on the fragment of road before narrowing, which was $2376.30 \mathrm{pcu} / \mathrm{hour}$. The maximum density found on the fragment of road during narrowing was $322.33 \mathrm{pcu} / \mathrm{hour}$, and the highest free speed regarding to the road condition before the narrowing was $57.21 \mathrm{~km} / \mathrm{hour}$. The relation between flow, speed and density showed a significant result (R2>0.5). Shock waves obtained were in the mornings and afternoons on Wednesday and Saturday.
\end{abstract}

Keywords: road narrowing, shock waves, free flow.

\section{Introduction}

Surabaya which is located on the north coast in East Java province becomes the second largest city in Indonesia after Jakarta. The area of Surabaya city reaches around $326.81 \mathrm{~km}^{2}$ along with 2,765,487 population of its inhabitants in 2017, it borders Madura Strait in the north and east, it borders Sidoarjo Regency on the south, and Gresik Regency in the west. There are a total of 160 urban villages around its 31 sub-districts [1].

The total of road network in Surabaya is $2,063.04 \mathrm{~km}$. Similar to other Cities, the problem comes from the management of road infrastructure which is still being evaluated by the Surabaya Government. Road infrastructure plays an important role in Surabaya economic growth so that it is able to suffice and accommodate the high mobility of Surabaya citizens. Hence, the Surabaya Government puts in the efforts continuously for the improvement. For instance, the Surabaya Government has built the new roads and widened its certain sections. Regardless the efforts done by the Surabaya Government, the management had not been maximally done on several road points. For instance was Ahmad Yani street at the front of Royal Plaza.

\section{Literature Review}

The speed of traffic, known as "S" notation is the motion of vehicle within a time unit distance [2]. Volume is defined as the number of vehicle passing a certain point per unit time at a particular location [3]. Density means the average number of vehicles per unit length of a certain lane and time [4]. Greenshield model was the earliest model used to observe the traffic behavior. Greenshield (1934) conducted a research focusing on the road lane in Ohio, USA, whose the traffic conditions met the requirement since there were no interruption and free movement (study state conditions). Shock waves happened due to the changes of traffic density as it caused by the obstruction on free traffic flow, This condition found on roads due to certain construction such as traffic accidents, road repair and others incidental things or as the result of road lane narrowing which is permanent. Besides that it is also found whether or not at a signalized intersection. The normal shock waves at signalized intersection are caused by red and green lights that appear periodically [5].

\section{Method}

The field data collection was carried out on Wednesday and Saturday. It was conducted for 12 hours per day at 06:00-18:00 with observational time interval per 10 minutes. The data retrieval of volume and speed was done at 3 points namely normal road condition, road narrowing condition and road condition after narrowing. The primary survey was held to obtain the volume and speed data. The speed data were obtained by recording the travel time of vehicles on the fragment of observation road by taking the data of light vehicles randomly 
at 10 minutes interval. While the volume data were taken by recording all types of vehicles that cross the observation line at the research location with an observation time interval per 10 minutes. Then the data were summed up per 1 hour according to each type of vehicle and converted into passenger car unit (pcu) by multiplying each type of vehicle with the value of passenger car equivalent (pce). After knowing all the values of the model parameters by regression analysis, the researchers calculated the extent of the accuracy of the regression function by looking for the value of the coefficient of determination as well as the $\mathrm{t}$ test and $\mathrm{F}$ test significance.

\section{Results and Discussion}

The results of the analysis of the calculation of the value of speed, density and volume obtained from the results of research in the field were in the form of the number of vehicles and the average speed of the room. By using regression analysis from the above data, the mathematical relationship between density, speed and volume was obtained as follows:

Table 1. Relationship of average speed of time, volume, and density (Wednesday, February 19, 2020)

\begin{tabular}{lllll}
\hline Location & Observation & Formula Model & Field Model & R2 \\
\hline $\begin{array}{l}\text { Fragment of the } \\
\text { road before }\end{array}$ & $\mathrm{St}-\mathrm{V}$ & $\mathrm{V}-\mathrm{D}=\mathrm{Dj} \cdot \mathrm{St}-(\mathrm{Dj} / \mathrm{St}) \cdot \mathrm{St}^{2}$ & $\mathrm{~V}=156,431 \mathrm{St}-2,406 \mathrm{St}^{2}$ & 0,842 \\
narrowing & $\mathrm{St}-\mathrm{D}$ & $\mathrm{V}=\mathrm{S}_{\mathrm{ff}} \mathrm{D}-\left(\mathrm{S}_{\mathrm{ff}} / \mathrm{Dj}^{2}\right) \mathrm{D}^{2}$ & $\mathrm{~V}=65,016 \mathrm{D}-0,41562 \mathrm{D}^{2}$ & 0,958 \\
& $\mathrm{~S}=\mathrm{S}_{\mathrm{ff}}-\left(\mathrm{S}_{\mathrm{ff}} / \mathrm{Dj}\right) \cdot \mathrm{D}$ & $\mathrm{S}=65,016-0,41562 \mathrm{D}$ & 0,867 \\
$\begin{array}{l}\text { Fragment of the } \\
\text { road during }\end{array}$ & $\mathrm{St}-\mathrm{V}$ & $\mathrm{V}-\mathrm{D}=\mathrm{Dj} \cdot \mathrm{St}-(\mathrm{Dj} / \mathrm{St}) \cdot \mathrm{St}^{2}$ & $\mathrm{~V}=322,331 \mathrm{St}-11,6036 \mathrm{St}^{2}$ & 0,480 \\
$\begin{array}{l}\text { narrowing } \\
\text { Fragment of the }\end{array}$ & $\mathrm{St}-\mathrm{D}$ & $\mathrm{V}=\mathrm{S}_{\mathrm{ff}} \mathrm{D}-\mathrm{V}-\left(\mathrm{S}_{\mathrm{ff}} / \mathrm{Dj}\right) \cdot \mathrm{D}^{2}$ & $\mathrm{~V}=27,778 \mathrm{D}-0,08618 \mathrm{D}^{2}$ & 0,697 \\
$\begin{array}{l}\text { road after } \\
\text { narrowing }\end{array}$ & $\mathrm{V}-\mathrm{D}=\mathrm{S}_{\mathrm{ff}}-\left(\mathrm{S}_{\mathrm{ff}} / \mathrm{Dj}\right) \cdot \mathrm{D}$ & $\mathrm{S}=27,778-0,08618 \mathrm{D}$ & 0,904 \\
& $\mathrm{St}-\mathrm{D}$ & $\mathrm{V}=\mathrm{Dj} \cdot \mathrm{St}-(\mathrm{Dj} / \mathrm{St}) \cdot \mathrm{St}^{2}$ & $\mathrm{~V}=265,550 \mathrm{St}-5,33677 \mathrm{St}^{2}$ & 0,203 \\
\hline
\end{tabular}

Table 2. Relationship of average speed of time, volume, and density (Saturday, February 22, 2020)

\begin{tabular}{|c|c|c|c|c|}
\hline Location & Observation & Formula Model & Field Model & $\mathbf{R 2}$ \\
\hline \multirow{3}{*}{$\begin{array}{l}\text { Fragment of the } \\
\text { road before } \\
\text { narrowing }\end{array}$} & St - V & $\mathrm{V}=\mathrm{Dj} \cdot \mathrm{St}-(\mathrm{Dj} / \mathrm{St}) \cdot \mathrm{St}^{2}$ & $\mathrm{~V}=145,124 \mathrm{St}-2,20016 \mathrm{St}^{2}$ & 0,750 \\
\hline & $\mathrm{V}-\mathrm{D}$ & 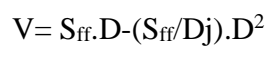 & $V=65,961 \mathrm{D}-0,45451 \mathrm{D}^{2}$ & 0,918 \\
\hline & St - D & $S=S_{f f}-\left(S_{f f} / D j\right) \cdot D$ & $S=65,961-0,45451 D$ & 0,815 \\
\hline \multirow{3}{*}{$\begin{array}{l}\text { Fragment of the } \\
\text { road during } \\
\text { narrowing }\end{array}$} & $\mathrm{St}-\mathrm{V}$ & $\mathrm{V}=\mathrm{Dj} \cdot \mathrm{St}-(\mathrm{Dj} / \mathrm{St}) \cdot \mathrm{St}^{2}$ & $V=290,799 \mathrm{St}-9,62083 \mathrm{St}^{2}$ & 0,724 \\
\hline & $\mathrm{V}-\mathrm{D}$ & $V=S_{f f} \cdot D-\left(S_{f f} / D j\right) \cdot D^{2}$ & $V=30,226 \mathrm{D}-0,10394 \mathrm{D}^{2}$ & 0,781 \\
\hline & St - D & $S=S_{f f}-\left(S_{f f} / D j\right) . D$ & $S=30,226-0,10394 \mathrm{D}$ & 0,955 \\
\hline \multirow{3}{*}{$\begin{array}{l}\text { Fragment of the } \\
\text { road after } \\
\text { narrowing }\end{array}$} & $\mathrm{St}-\mathrm{V}$ & $\mathrm{V}=\mathrm{Dj} \cdot \mathrm{St}-(\mathrm{Dj} / \mathrm{St}) \cdot \mathrm{St}^{2}$ & $\mathrm{~V}=169,767 \mathrm{St}-3,0784 \mathrm{St}^{2}$ & 0,671 \\
\hline & $\mathrm{V}-\mathrm{D}$ & 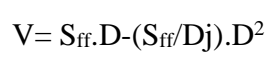 & $V=55,147 D-0,32484 D^{2}$ & 0,876 \\
\hline & St - D & $S=S_{f f}-\left(S_{f f} / D j\right) . D$ & $S=55,147-0,32484 \mathrm{D}$ & 0,880 \\
\hline
\end{tabular}

The value of coefficient of determination (R2) showed the influence of the independent variable (X) on the dependent variable (Y). The variable tested in this research was the $t$ test, which was the control tool of the statistical analysis result, in this case linear regression, by comparing the values of $\mathrm{F}$ and $\mathrm{t}$ count and values of $\mathrm{F}$ and $\mathrm{t}$ table. The tests were considered true if the values of $\mathrm{F}$ and $\mathrm{t}$ count were greater than the values of $\mathrm{F}$ and $\mathrm{t}$ table.

Table 3. Results of F and t tests

\begin{tabular}{|c|c|c|c|}
\hline Wednesday, February 19, 2020 & & Saturday, February 22, 2020 & \\
\hline Location & Test result & Location & Test result \\
\hline $\begin{array}{l}\text { Fragment of the road before } \\
\text { narrowing }\end{array}$ & $\begin{array}{l}F=424,426 \\
t=74,658\end{array}$ & $\begin{array}{l}\text { Fragment of the road before } \\
\text { narrowing }\end{array}$ & $\begin{array}{l}F=288,610 \\
t=56,916\end{array}$ \\
\hline $\begin{array}{l}\text { Fragment of the road during } \\
\text { narrowing }\end{array}$ & $\begin{array}{l}F=615,545 \\
t=62,981\end{array}$ & $\begin{array}{l}\text { Fragment of the road during } \\
\text { narrowing }\end{array}$ & $\begin{array}{l}F=1334,76 \\
t=87,359\end{array}$ \\
\hline $\begin{array}{l}\text { Fragment of the road after } \\
\text { narrowing }\end{array}$ & $\begin{array}{l}F=58,080 \\
t=41,657\end{array}$ & $\begin{array}{l}\text { Fragment of the road after } \\
\text { narrowing }\end{array}$ & $\begin{array}{l}F=475,544 \\
t=68,983\end{array}$ \\
\hline
\end{tabular}


F table value $=3,14$

T table value $=1,99714$

It can be seen that the F and t count values were greater than the F and table values at the $95 \%$ confidence level, thus the model can be used.

\subsection{SHOCK WAVE VALUE}

The value of the shock wave $(\omega)$ on the road narrowing began by plotting demand, upstream, and supply based on the selected maximum flow. Shock wave analysis can be done if demand exceeds supply [6].

$\omega=\frac{V 1-V 2}{d 1-d 2}$

$\omega=$ shock wave $(\mathrm{km} /$ hour $)$

$\mathrm{V} 1=$ traffic flow of area 1 (pcu/hour)

$\mathrm{V} 2=$ traffic flow of area 2 (pcu/hour)

$\mathrm{D} 1=$ traffic density of area $1(\mathrm{pcu} / \mathrm{km})$

D2 $=$ traffic density of area $2(\mathrm{pcu} / \mathrm{km})$

Table 4. Shock wave calculation on Wednesday, February 19, 2020

\begin{tabular}{|c|c|c|c|c|c|}
\hline Time Period & $\begin{array}{l}\text { Traffic Flow } \\
\text { of Area I }\end{array}$ & $\begin{array}{l}\text { Traffic Flow } \\
\text { of Area II }\end{array}$ & $\begin{array}{l}\text { Traffic } \\
\text { Density of } \\
\text { Area I }\end{array}$ & $\begin{array}{l}\text { Traffic } \\
\text { Density of } \\
\text { Area II } \\
\end{array}$ & $\begin{array}{l}\text { Shock Wave } \\
\text { Speed }\end{array}$ \\
\hline & (pcu/hour) & (pcu/hour) & $(\mathrm{pcu} / \mathbf{k m})$ & (pcu/hour) & (km/hour) \\
\hline 06:00 - 07:00 & 2376,3 & 2238,46 & 57,21 & 322,33 & $-0,51992$ \\
\hline $06: 10-07: 10$ & 2390,7 & 2238,46 & 56,08 & 322,33 & $-0,57180$ \\
\hline $06: 20-07: 20$ & 2390,2 & 2238,46 & 56,07 & 322,33 & $-0,56990$ \\
\hline $06: 30-07: 30$ & 2399,6 & 2238,46 & 56,29 & 322,33 & $-0,60570$ \\
\hline $06: 40-07: 40$ & 2406,2 & 2238,46 & 54,96 & 322,33 & $-0,62737$ \\
\hline $06: 50-07: 50$ & 2403,3 & 2238,46 & 54,89 & 322,33 & $-0,61637$ \\
\hline 07:00 - 08:00 & 2378,5 & 2238,46 & 55,79 & 322,33 & $-0,52542$ \\
\hline 07:10 - 08:10 & 2348,4 & 2238,46 & 53,64 & 322,33 & $-0,40918$ \\
\hline $07: 20-08: 20$ & 2321,4 & 2238,46 & 54,45 & 322,33 & $-0,30963$ \\
\hline $07: 30-08: 30$ & 2300,3 & 2238,46 & 51,12 & 322,33 & $-0,22803$ \\
\hline $07: 40-08: 40$ & 2269,8 & 2238,46 & 51,84 & 322,33 & $-0,11588$ \\
\hline $07: 50-08: 50$ & 2242,2 & 2238,46 & 49,83 & 322,33 & $-0,01374$ \\
\hline 08:00 - 09:00 & 2209,4 & 2238,46 & 51,83 & 322,33 & 0,10742 \\
\hline $16: 00-17: 00$ & 2323,9 & 2238,46 & 43,78 & 322,33 & $-0,30675$ \\
\hline $16: 10-17: 10$ & 2338,2 & 2238,46 & 46,29 & 322,33 & $-0,36133$ \\
\hline $16: 20-17: 20$ & 2361,4 & 2238,46 & 41,54 & 322,33 & $-0,43785$ \\
\hline $16: 30-17: 30$ & 2373,5 & 2238,46 & 41,54 & 322,33 & $-0,48094$ \\
\hline $16: 40-17: 40$ & 2397,6 & 2238,46 & 42,63 & 322,33 & $-0,56898$ \\
\hline $16: 50-17: 50$ & 2409,9 & 2238,46 & 41,54 & 322,33 & $-0,61057$ \\
\hline $17: 00-18: 00$ & 2070 & 2238,46 & 41,54 & 322,33 & 0,59993 \\
\hline
\end{tabular}

Table 5. Shock wave calculation on Saturday, February 22, 2020

\begin{tabular}{|c|c|c|c|c|c|}
\hline Time Period & $\begin{array}{l}\text { Traffic Flow } \\
\text { of Area I }\end{array}$ & $\begin{array}{l}\text { Traffic Flow } \\
\text { of Area II }\end{array}$ & $\begin{array}{l}\text { Traffic } \\
\text { Density of } \\
\text { Area I } \\
\end{array}$ & $\begin{array}{l}\text { Traffic } \\
\text { Density } \\
\text { Area II } \\
\end{array}$ & $\begin{array}{l}\text { Shock } \\
\text { Speed }\end{array}$ \\
\hline & (pcu/hour) & (pcu/hour) & (pcu/hour) & (pcu/hour) & (km/hour) \\
\hline 06:00 - 07:00 & 2323,60 & 2197,43 & 46,29 & 290,80 & $-0,51601$ \\
\hline $06: 10-07: 10$ & 2323,80 & 2197,43 & 43,78 & 290,80 & $-0,51160$ \\
\hline $06: 20-07: 20$ & 2329,60 & 2197,43 & 42,63 & 290,80 & $-0,53259$ \\
\hline $06: 30-07: 30$ & 2324,30 & 2197,43 & 41,54 & 290,80 & $-0,50899$ \\
\hline $06: 40-07: 40$ & 2314,40 & 2197,43 & 41,54 & 290,80 & $-0,46928$ \\
\hline $06: 50-07: 50$ & 2308,80 & 2197,43 & 40,50 & 290,80 & $-0,44496$ \\
\hline 07:00 - 08:00 & 2299,60 & 2197,43 & 41,54 & 290,80 & $-0,40990$ \\
\hline $07: 10-08: 10$ & 2282,50 & 2197,43 & 41,54 & 290,80 & $-0,34130$ \\
\hline
\end{tabular}




\begin{tabular}{llllll}
\hline $07: 20-08: 20$ & 2267,70 & 2197,43 & 41,54 & 290,80 & $-0,28192$ \\
$07: 30-08: 30$ & 2249,20 & 2197,43 & 41,54 & 290,80 & $-0,20770$ \\
$07: 40-08: 40$ & 2230,80 & 2197,43 & 41,54 & 290,80 & $-0,13388$ \\
$07: 50-08: 50$ & 2212,40 & 2197,43 & 42,63 & 290,80 & $-0,06033$ \\
$08: 00-09: 00$ & 2181,80 & 2197,43 & 41,54 & 290,80 & 0,06270 \\
$16: 00-17: 00$ & 2260,80 & 2197,43 & 43,78 & 290,80 & $-0,25655$ \\
$16: 10-17: 10$ & 2249,00 & 2197,43 & 43,78 & 290,80 & $-0,20878$ \\
$16: 20-17: 20$ & 2249,40 & 2197,43 & 43,78 & 290,80 & $-0,21040$ \\
$16: 30-17: 30$ & 2261,40 & 2197,43 & 42,63 & 290,80 & $-0,25778$ \\
$16: 40-17: 40$ & 2276,50 & 2197,43 & 45,00 & 290,80 & $-0,32169$ \\
$16: 50-17: 50$ & 2285,40 & 2197,43 & 38,57 & 290,80 & $-0,34878$ \\
$17: 00-18: 00$ & 1966,30 & 2197,43 & 40,50 & 290,80 & 0,92341 \\
\hline
\end{tabular}

As an example, the calculation was done to the data taken on Wednesday on the period of time 06:00-07:00:

a. A demand of $2376.30 \mathrm{pcu} / \mathrm{hour}$ with the road capacity of traffic flow of area 2 as much $2238.46 \mathrm{pcu} /$ hour resulted in a backward forming shock waves.

b. From the model, the equation obtained was $V=65,016 \mathrm{D}-0,41562 \mathrm{D}^{2}$ the value of traffic density of area 1 was obtained by adding the value of traffic flow of area 1 to the equation and the value of traffic density of area 2 was obtained by adding the value of traffic flow of area 2 . Therefore, the values of traffic density of area 1 obtained $=57.21 \mathrm{pcu} / \mathrm{km}$ and traffic density of area $2=322.33 \mathrm{pcu} /$ $\mathrm{km}$.

\section{Conclusion}

From all of the calculations, the data processing, and the discussion, the following conclusions were drawn:

1. The largest free speed $\left(\mathrm{S}_{\mathrm{ff}}\right)$ was on the fragment of road before narrowing and decreased on the fragment of road during narrowing and increased one more time on the fragment of road after narrowing. The biggest density $\left(D_{j}\right)$ was on the fragment of road during narrowing and then decreased on the fragment of road after narrowing. The highest maximum volume $(\mathrm{Vm})$ was found on the fragment of road after narrowing.

2. There was a significant correlation $\left(\mathrm{R}^{2}>0.5\right)$ between flow, speed, and density.

3. Based on the survey conducted on Wednesday and Saturday, there were shock waves as follows: on Wednesday at 06:00 to 09:00 (the backward forming shock wave was $0.51992 \mathrm{~km} /$ hour, the forward recovery shock wave was 0.10742 km/hour), 16:00 - 18:00 (the backward forming shock wave was $0.30675 \mathrm{~km} /$ hour, the forward recovery shock wave was $0.59993 \mathrm{~km} / \mathrm{hour}$ ). Moreover, on Saturday 07:00 - 09:00 (the backward forming shock wave was $0.51601 \mathrm{~km} /$ hour, and the forward recovery shock wave was $0.06270 \mathrm{~km} / \mathrm{hour}$ ), 16:00 - 18:00 (the backward forming shock wave was $0.25655 \mathrm{~km} /$ hour, the forward recovery shock wave was $0.92341 \mathrm{~km} / \mathrm{hour}$ ).

\section{References}

[1] S. Riyadi, D. Susilo, S. A. Sufa, and T. Dwi Putranto, "Digital marketing strategies to boost tourism economy: A case study of atlantis land Surabaya," Humanit. Soc. Sci. Rev., vol. 7, no. 5, 2019, doi: 10.18510/hssr.2019.7553.

[2] V. Petraki, A. Ziakopoulos, and G. Yannis, "Combined impact of road and traffic characteristic on driver behavior using smartphone sensor data,” Accid. Anal. Prev., vol. 144, 2020, doi: 10.1016/j.aap.2020.105657.

[3] N. Abdull, M. Yoneda, and Y. Shimada, "Traffic characteristics and pollutant emission from road transport in urban area," Air Qual. Atmos. Heal., vol. 13, no. 6, 2020, doi: 10.1007/s11869-020-00830-w.

[4] J. Weng, S. Liao, B. Wu, and D. Yang, "Exploring effects of ship traffic characteristics and environmental conditions on ship collision frequency," Marit. Policy Manag., vol. 47, no. 4, 2020, doi: 10.1080/03088839.2020.1721584.

[5] M. Petkovšek, M. Hočevar, and M. Dular, "Visualization and measurements of shock waves in cavitating flow," Exp. Therm. Fluid Sci., vol. 119, 2020, doi: 10.1016/j.expthermflusci.2020.110215.

[6] I. M. Martínez, N. Sempere-Rubio, O. Navarro, and R. Faubel, "Effectiveness of shock wave therapy as a treatment for spasticity: A systematic review," Brain Sciences, vol. 11, no. 1. 2021, doi: 10.3390/brainsci11010015. 